Konflik Dalam Hubungan Industrial Ditinjau Dari Aspek Sosiologi Industri: Suatu Survey Pada Industri Garmen di Kabupaten Bandung (Nandan Limakrisna)

\title{
KONFLIK DALAM HUBUNGAN INDUSTRIAL DITINJAU DARI ASPEK SOSIOLOGI INDUSTRI: Suatu Survey Pada Industri Garmen di Kabupaten Bandung
}

\author{
Nandan Limakrisna \\ Fakultas Ekonomi Program Pascasarjana Universitas Persada Indonesia Y.A.I \\ Jl. Diponegoro no. 74 Menteng Jakarta Pusat \\ Email : amarta.nandan@gmail.com
}

\begin{abstract}
ABSTRAK. Penelitian ini bertujuan untuk : Mempelajari pandangan para pengusaha garmen di Wilayah Bandung dan Sekitarnya (mencakup pandangan tradisional atau pandangan modern) pada konflik yang dibayangkan dan konflik yang dirasakan. Menganalisis tingkat pengaruh aturan pemerintah (meliputi perundangan, kebijakan, dan keputusan pemerintah) terhadap konflik yang dirasakan dalam hubungan industrial. Menganalisis tingkat pengaruh nilai-nilai sosial terhadap konflik yang dirasakan dalam hubungan industrial. Menganalisis tingkat pengaruh hubungan kerja (meliputi ketergantungan, perbedaan dalam tujuan, perbedaan persepsi, dan kebutuhan spesialis) terhadap konflik yang dirasakan dalam hubungan industrial. Menganalisis tingkat pengaruh konflik yang dirasakan yang mencakup ambiguitas peranan, persaingan untuk mencapai sumber-sumber daya langka, interdependensi tugas, kendala-kendala komunikasi, konflik sebelumnya, perbedaan persepsi individual, dan perbedaan dalam kepribadian, kebutuhan-kebutuhan, nilai-nilai, serta tujuan-tujuan dalam hubungan industrial terhadap produktivitas kerja. Berdasarkan hasil pengolahan data, maka didapatkan bahwa para pengusaha garment di wilayah Bandung dan sekitarnya masih berpandangan tradisional terhadap konflik. Aturan pemerintah yang cenderung memihak pengusaha ternyata memiliki pengaruh yang berarti terhadap timbulnya konflik sebesar 38,1\%. Demikian juga nilai-nilai sosial karyawan berpengaruh terhadap timbulnya konflik, tetapi pengaruhnya relatif kecil, yaitu $5,20 \%$. Sedangkan hubungan kerja di perusahaan memiliki pengaruh yang cukup besar terhadap timbulnya konflik, yaitu sebesar $27,2 \%$. Tetapi konflik yang tereskalat/ timbul berpengaruh sangat berarti terhadap produktivitas kerja sebesar 62,9\%.
\end{abstract}

Kata Kunci: Konflik, Hubungan Industrial, aturan pemerintah, nilai-nilai sosial, hubungan kerja

ABSTRACT. This study aims to: Learn the views of garment entrepreneurs in Bandung and Surrounding Areas (including the traditional view or the modern view) on the conflicts and perceived conflicts imaginable. Analyzing the level of influence of government regulations (including laws, policies and government decisions) against a perceived conflict in industrial relations. Analyzing the level of influence of social values 
against the perceived conflict in industrial relations. Analyzing the level of influence of labor (including dependencies, different goals, different perceptions, and needs specialist) on the perceived conflict in industrial relations. To analyze the influence of the level of perception that includes ambiguity role conflict, competition for scarce resources achieve, task interdependence, communication constraints, previous conflicts, differences in individual perceptions, and differences in personality, needs, values and goals in industrial relations on productivity work. Based on data processing, it was found that the garment entrepreneurs in Bandung and its surrounding area is still a traditional view of conflict. government regulations that tend to side with employers proved to have significant influence on the occurrence of conflict of $38.1 \%$. Similarly, employees who influence the social values in conflict, but the effect is relatively small, namely $5.20 \%$. While working at the company has a major influence on the occurrence of conflict, that is equal to $27.2 \%$. But conflicts that tereskalat / incurred a very significant impact on labor productivity amounted to $62.9 \%$.

Keywords: conflict, industrial relationship, goverment policy, social values, work relationship.

\section{PENDAHULUAN}

Indonesia sekarang sedang menghadapi krisis ekonomi yang berkepanjangan yang dimulai pada tahun 1997, ini memberikan dampak sosial yang sangat berarti, salah satunya adalah adanya pemutusan hubungan kerja secara massal pada industriindustri yang dinyatakan sudah tidak efektif dan efesien lagi. Menurut data P4-Pusat (Desember, 1999), selama tahun 2009 terdapat 2256 perkara dan 106.481 orang tenaga kerja yang mendapatkan pemutusahan hubungan kerja (PHK), dimana lebih dari $50 \%$ perkara dan tenaga kerja yang mendapatkan PHK berasal dari industri tekstil khususnya industri garmen. Oleh karena itu sebagai akibat dari pemutusan hubungan kerja secara massal tersebut ada kecenderungan peningkatan jumlah penduduk yang miskin di Indonesia (Indonesia dalam angka, 2010).

Industri tekstil Indonesia mulai berkembang tahun tujuh puluhan sebagai jawaban terhadap kebutuhan pasar domestik dan peluang ekspor yang cukup menjanjikan. Perkembangan yang cukup pesat tersebut menyebabkan industri tekstil telah memberi peran yang sangat dominan terhadap perekonomian Indonesia. Peranan industri tekstil dapat dilihat dari kontribusinya terdahap nilai tambah dan penyerapan tenaga kerja. Dari Direktori Industri Pengolahan (BPS,2010:322) diperoleh data bahwa jumlah perusahaan industri tekstil yang terdaftar di seluruh Indonesia sebanyak 2.212 yang melibatkan 626.720 tenaga kerja, sedangkan industri pakaian jadi sebanyak 1.802 dengan jumlah tenaga kerja sebanyak 348.497. Nilai tambah dari industri tekstil sebesar $22,80 \%$ dan pakaian jadi sebesar $5,45 \%$. Bila dilihat dari 
Konflik Dalam Hubungan Industrial Ditinjau Dari Aspek Sosiologi Industri: Suatu Survey Pada Industri Garmen di Kabupaten Bandung (Nandan Limakrisna)

aspek geografis, sebaran industri tekstil terkonsentrasi di Jawa Barat (47,34 \%), sedangkan pakaian jadi lebih terkonsentrasi di DKI Jakarta dan Wilayah Bandung dan Sekitarnya yaitu sebanyak 29,11 \% dan $20,1 \%$.

Di masa lalu salah satu "keunggulan" industri tekstil Indonesia untuk bersaing di pasar dunia adalah upah tenaga kerja yang rendah. Keunggulan itu menarik bagi investor luar negeri karena dapat menekan biaya produksi, namun di sisi lain kesejahteraan pekerja Indonesia sangat memprihatinkan. Keadaan demikian antara lain terlihat dalam data tahun 1986 menunjukkan bahwa upah rata-rata pekerja di Indonesia lebih rendah 35 kali lipat dari pada upah pekerja di negara Jepang, Jerman Barat dan Inggris atau dua kali lebih rendah dari Filipina (Poot dalam Wie, 2006 ; 267). Data lain dari Morgan Stanley Research pada tahun 1991, Indonesia menempati ranking ke 37 dari 38 negara yang diteliti dengan upah rata-rata US\$ 0.22 per jam, satu tingkat di atas Rusia yang menempati peringkat terakhir dengan US $\$ 0.03$ per jam (Herlina, 2007). Demikian pula produktivitas kerja yang diperlihatkan dalam bentuk nilai tambah per pekerja masih ketinggalan dari negara-negara lain

Menurut Winardi (1994; 15), Konflik yang terjadi dan kurang mampunya penerapan konsep hubungan yang harmonis disebabkan oleh kondisi antenseden-antenseden konflik yang seringkali dapat diketemukan pada ambiguitas peranan, persaingan untuk mencapai sumber-sumber daya langka, interdependensi tugas, kendala-kendala komunikasi, konflik sebelumnya, perbedaan persepsi individual, dan perbedaan dalam kepribadian, kebutuhan-kebutuhan, nilai-nilai, serta tujuan-tujuan, terutama dalam menciptakan sinergi antara lingkungan kerja, nilai-nilai, dan sumber daya.

Konflik merupakan perjuangan antara kebutuhan, keinginan, gagasan, kepentingan ataupun pihak saling bertentangan. Dengan perkataan lain konflik timbul karena ketidaksesuaian (incongruency) dalam: (1) sasaran (goal), (2) nilai (values), (3) pikiran (cognition), (4) perasaan (affect) dan (5) perilaku (behavior). (Sedarmayanti, 2000:137).

Menurut Stephen P. Robins (1996:125-135) ada beberapa pandangan mengenai konflik (1) pandangan tradisional mengenai konflik. Keyakinan bahwa semua konflik merugikan dan harus dihindari, (2) pandangan hubungan manusia mengenai konflik. Keyakinan bahwa konflik merupakan hasil wajar dan tidak terelakkan dalam setiap kelompok, (3) pandangan interaksionis mengenai konflik. Keyakinan bahwa konflik tidak hanya suatu kekuatan positif dalam suatu kelompok melainkan juga mutlak perlu untuk suatu kelompok agar dapat berkinerja efektif, (4) konflik fungsional. Konflik yang mendukung tujuan kelompok dan memperbaiki kinerja kelompok, (5) konflik disfungsional. Konflik yang merintangi kinerja kelompok.

Istilah konflik industrial mengacu kepada hubungan antara pemilik atau majikan dan manajemen di satu pihak dengan para buruh di pihak lain. Para sosiolog industrial secara umum sepakat bahwa konflik-konflik industrial memiliki manifestasi yang 
bervariasi. Konflik-konflik seperti pemogokan, sabotase, restruksi output, nonkooperasi, dan lain sebagainya dapat terjadi dalam basis individual maupun kolektif. ( Abercrombie ed. al; The Dictionary of Sociology, Penguin, London, 1984: 121). Semua hal tersebut adalah konflik-konflik yang terbuka dalam hubungan-hubungan industrial. Lainnya "terselubung" atau "tersembunyi" dan dikenal sebagai "konflik laten"

Terdapat bermacam-macam strategi untuk menghindari konflik tergantung pada tingkat atau besarnya birokrasi dalam kelompok. Di dalam organisasi birokrasi yang besar, dapat dikembangkan prosedur resmi untuk merembukkan perbedaanperbedaan. Sebaliknya, dalam kelompok kecil, akan muncul prosedur yang kurang formal untuk mengatasi berbagai perbedaan (Coser, 1956).

Ada dua kensekuensi jika konflik itu dipendam. Pertama, dipendamnya konflik dapat mengakibatkan putusnya hubungan. Jika keterlibatan emosional para anggota kelompok sudah tinggi, berakhirnya hubungan itu mungkin dipercepat dengan meledaknya konflik secara tiba-tiba dan parah, dimana ketegangan dan permusuhan yang menggunung sejak masa lampau meledak dalam bentuk amukan yang keras. Sebaliknya, kalau hubungan itu bersifat sekunder, putusnya hubungan yang ditimbulkan oleh konflik yang terpendam mungkin hanya berupa sikap apatis yang semakin bertambah dan akhirnya menarik diri.

Konsekuensi kedua, yang mungkin terjadi karena dipendamnya konflik adalah mengelakkan perasaan bermusuhan dari sumber yang sebenarnya, dan mengembangkan saluran alternatif untuk mengungkapkannya. Alternatif demikian adalah semacam katup pengamanan sebagai sarana untuk mengungkapkan dorongandorongan agresif atau permusuhan dengan cara-cara yang tidak mengancam solidaritas. Katup-katup pengaman ini dapat berbentuk pengungkapan kebencian atau permusuhan secara jenaka atau lelucon. Atau dalam hal sikap agresif dan permusuhan dapat dilakukan melalui kompetisi atau upacara-upacara lain. Selanjutnya Coser membedakan antara konflik realistik dan konflik non-realistik. Konflik realistik adalah alat untuk mencapai suatu tujuan tertentu, yang jika tujuan tersebut tercapai mungkin akan menghilangkan sebab-sebab dasar dari konflik. Sebaliknya, konflik non-realistik mencakup ungkapan permusuhan sebagai tujuannya sendiri. Konflik realistik diarahkan kepada obyek konflik, sedangkan konflik non-realistik membelok dari obyek konflik yang sebenarnya. Konflik realistik sering menjadi perangsang utama bagi perubahan sosial.

Winardi $(1994 ; 15)$ mengemukakan bahwa terdapat gejala-gejala antesenden yang dapat menjadi suatu indikator terjadinya konflik, yaitu peranan ganda, persaingan dalam mencapai sumberdaya langka, interdependensi tugas, konflik sebelumnya yang belum terselesaikan, perbedaan perbedaan dalam tujuan, persepsi, dan nilai-nilai yang semua gejala tersebut menjadi dasar bagi perusahaan dalam mempersepsi konflik yang akan terjadi dan merasakan konflik yang sudah terjadi. 
Konflik Dalam Hubungan Industrial Ditinjau Dari Aspek Sosiologi Industri: Suatu Survey Pada Industri Garmen di Kabupaten Bandung (Nandan Limakrisna)

Kesenjangan dari konlfik yang dipersepsi dengan konflik yang dirasakan akan menimbulkan konflik yang memanifestasi diri dalam hubungan industrial yang menuntut penyelesaian persoalan-persoalan konflik dari pihak manajemen yang akhirnya mencapai hasil dari penyelesaian konflik tersebut yaitu produktivitas kerja. Berdasarkan pendapat Winardi dan para ahli sosiologi lainnya tersebut dapat difahami bahwa suatu perusahaan dikatakan memiliki pandangan tradisional terhadap konflik yang memanifestasi diri dalam hubungan industrial apabila konflik yang dirasakan lebih besar dari pada konflik yang dipersepsi oleh perusahaan, artinya perusahaan tidak begitu memperhatikan gejala-gejala konflik yang ada, sehingga tidak melakukan perbaikan-perbaikan yang berarti dan akhirnya akan menimbulkan konflik yang negatif/ tereskalasi, pada keadaan seperti itu perusahaan lebih memilih untuk menekan secara otoriter terhadap konflik yang terjadi (win-lose solusion), sehingga produktivitas akan menurun. Demikian juga sebaliknya suatu perusahaan memiliki pandangan modern terhadap konflik apabila konflik yang dirasakan lebih kecil dari pada konflik yang dipersepsi, artinya mereka lebih mengantisifasi keadaan konflik berdasarkan gejala-gejala antesenden konflik dengan perbaikan-perbaikan yang berarti, sehingga menimbulkan konflik yang positif/ fungsional, pada kondisi seperti ini perusahaan melakukan penyelesaian konflik secara win-win solusion yang akhirnya akan meningkatkan produktivitas kerja.

Produktivitas kerja dalam ekonomi berarti rasio dari hasil yang dicapai dengan pengorbanan yang dikeluarkan untuk menghasilkan sesuatu, (Encyclopedia Britanica, 1982 ; 27). Sedangkan menurut National Productivity Board (NPB) Singapore, dikatakan bahwa produktivitas adalah sikap mental (attitude of mind) yang mempunyai semangat untuk melakukan peningkatan perbaikan. Sehingga tingkat produktivitas yang dicapai merupakan suatu indikator terhadap efisiensi dan kemajuan ekonomi untuk ukuran suatu bangsa, suatu industri, maupun ukuran pendidikan.

Berdasarkan penelitian Haque dan Falk (2000) dalam journal of productivity, bahwa industri yang bergerak dalam bidang tekstil terutama garmen, lebih cocok menggunakan pengukuran produktivitas kerjanya berdasarkan standard direct labour hours to actual direct labour hours.

Bertolak dari kenyataan yang demikian inilah maka penelitian ini difokuskan kepada perusahaan/industri garmen di Wilayah Bandung dan Sekitarnya mengingat (1) konsentrasi industri garmen di Wilayah Bandung dan Sekitarnya cukup besar dari sekitar 250 perusahaan garmen di Jawa Barat dengan kriteria jumlah pekerja di atas 100, di Wilayah Bandung dan Sekitarnya terdapat 53 perusahaan. (2) industri garmen sangat potensial sumbangannya terhadap nilai tambah dan penyerapan tenaga kerja. 
Kerangka teoritis dapat digambarkan secara skematik sebagai berikut :

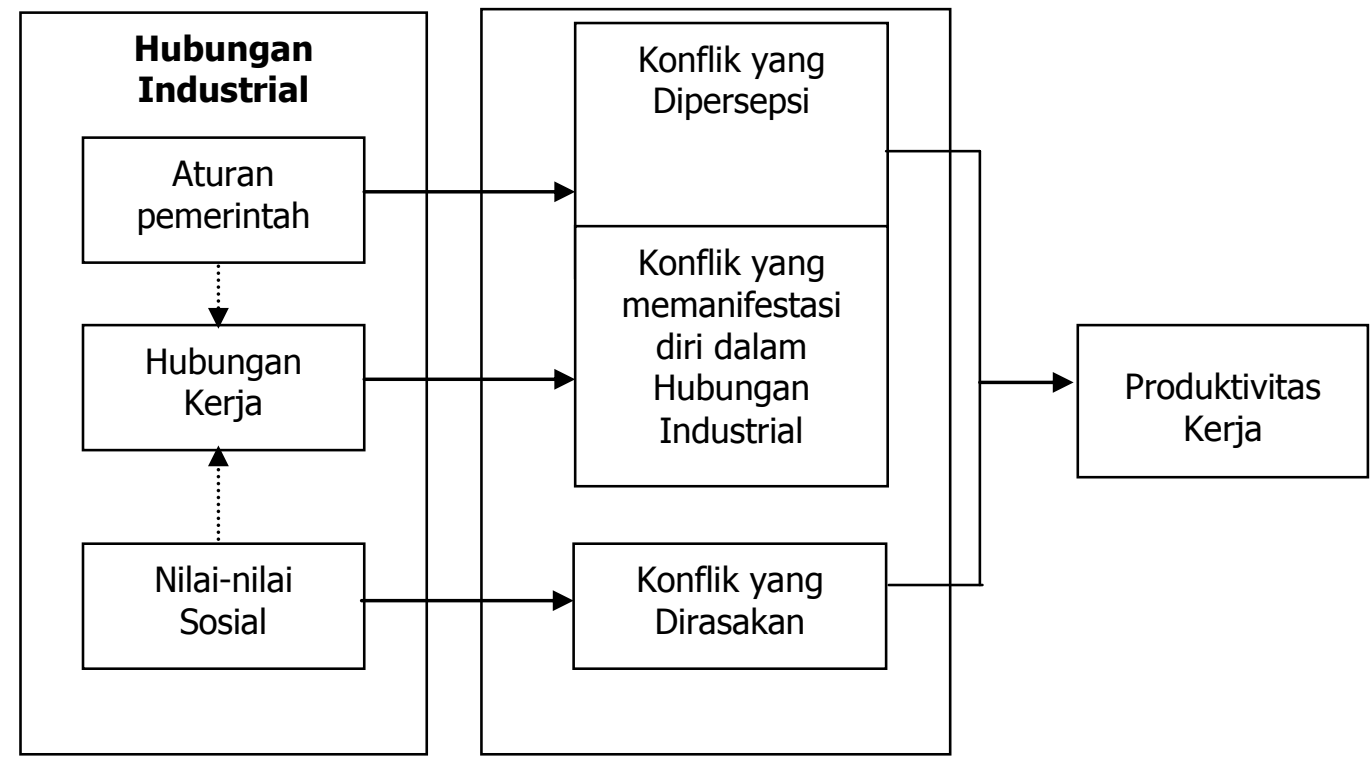

Dalam penelitian ini, fokus permasalahan diarahkan kepada pemberdayaan konflik dalam hubungan industrial yang mendukung peningkatan produktivitas kerja pada industri garmen di Wilayah Bandung dan Sekitarnya serta pandangan para pengusaha garment terhadap konflik yang dibayangkan (conflict perseption) dan konflik yang dirasakan (perceived conflict). Kesenjangan dari konflik yang dipersepsi dengan konflik yang dirasakan adalah merupakan konflik yang memanifestasi diri atau dalam penelitian ini disebut konflik dalam hubungan industrial. Karena itu pendekatan pada penelitian ini adalah menggunakan pendekatan ilmu sosiologi, khususnya sosiologi industri.

Dengan demikian pernyataan masalahnya (problem statement) adalah: "Orientasi perusahaan (para pengusaha) terhadap konflik yang menentukan tindakan para pengusaha dalam menghadapi konflik yang memanifestasi diri, apakah perusahaan melakukan penekan secara otoritar terhadap konflik (win-lose solution), sehingga akan mengakibatkan terjadinya konflik yang negatif/ tereskalasi yang akhirnya akan menyebabkan produktivitas kerja menurun". 


\section{METODE}

Mengingat sifat penelitian ini adalah deskriptif dan verifikatif yang dilaksanakan melalui pengumpulan data di lapangan, maka metode penelitian yang digunakan adalah metode descriptive survey dan metode explanatory survey. Tipe investigasi yang digunakan adalah kausalitas, yaitu tipe penelitian yang menyatakan ada pengaruh antara independent variable terhadap dependent variable. Unit analsis dari penelitian ini adalah individual yaitu, para pengusaha pada perusahaan-perusahaan garmen yang ada di Wilayah Bandung dan sekitarnya. Dilihat dari time horizomya, penelitian ini bersifat cross sactional, yaitu informasi dari populasi dikumpulkan langsung dikumpulkan langsung di tempat kejadian secara empirik, dengan tujuan untuk mengetahui pendapat dari populasi terhadap obyek yang sedang diteliti.

Dalam penelitian ini yang menjadi obyek penelitian sebagai independent variable (variabel bebas) adalah hubungan industrial yang terdiri dari perundang-undangan, nilai-nilai sosial, dan hubungan kerja, serta konflik dalam hubungan industral yang mencakup ambiguitas peranan, persaingan untuk mencapai sumber-sumber daya langka, interdependensi tugas, penghalang-penghalang terhadap komunikasi, konflikkonflik sebelumnya yang belum selesai, perbedaan dalam persepsi individual, dan perbedaan dalam kepribadian/ kebutuhan/ nilai-nilai/ tujuan. Obyek penelitian yang merupakan dependent variabel (variabel tak bebas) adalah produktivitas kerja.

Jumlah populasi perusahaan garmen di Wilayah Bandung dan sekitarnya sebanyak 53 perusahaan dan yang dijadikan responden pada setiap perusahaan adalah pengusaha/ manajer sebagai pengambil keputusan penting di perusahaannya. Karena pupolasi perusahaan relatif sedikit, maka yang dijadikan responden adalah 53 perusahaan.

\section{Metode Analisis}

Berdasarkan hipotesis konseptual yang diajukan terlihat bahwa hubungan antara variabel bisa merupakan hubungan regresi multipel/berganda atau regresi simpel/sederhana. Dengan demikian persamaan regresi multipelnya adalah :

$$
y=f\left(X_{\left.I, \ldots \ldots \ldots, X_{k}, \varepsilon\right)}\right.
$$

dan persamaan regresi sederhana adalah :

$$
y=f(X ; \varepsilon)
$$

Melalui paradigma dan persamaan regresi, maka hipotesis konseptual tersebut akan diuji melalui analisis korelasi pearson. 
Dalam hal ini $\mathrm{P} Y \mathrm{YX}_{1, \&} \mathrm{P} \mathrm{YX}_{2}$ merupakan koefisien korelasi. Struktur hubungan variabel tersebut dapat dinyatakan ke dalam persamaan regresi, yaitu :

$Y=b_{0}+b_{1} x_{1}+b_{2} x_{2}$

Koefisien korelasi dalam hal ini $r_{y x i}$ adalah korelasi antara variabel $X_{i}$ dan $Y$ dengan menggunakan rumus sebagai berikut:

$$
\mathrm{r}_{\mathrm{yxi}}=\frac{\mathrm{n} \sum_{\mathrm{h}=1}^{\mathrm{n}} \mathrm{X}_{\mathrm{ih}} \mathrm{Y}_{\mathrm{h}}-\left(\sum \mathrm{X}_{\mathrm{ih}}\right)\left(\sum \mathrm{Y}_{\mathrm{h}}\right)}{\sqrt{\left\{\mathrm{n} \sum_{\mathrm{h}=1}^{\mathrm{n}} \mathrm{X}_{\mathrm{ih}}{ }^{2}-\left(\sum \mathrm{X}_{\mathrm{ih}}\right)^{2}\right\}\left\{\mathrm{n} \sum_{\mathrm{h}=1}^{\mathrm{n}} \mathrm{Y}_{\mathrm{h}}{ }^{2}-\left(\sum_{\mathrm{h}=1}^{\mathrm{n}} \mathrm{Y}_{\mathrm{h}}{ }^{2}\right)\right\}}}
$$

$\mathrm{i}=1,2,3, \ldots, 5$ dan $\mathrm{k}=$ banyaknya variabel bebas

Hipotesis 1 dibahas secara deskriptif dengan menggunakan analisis tabulasi/ tabel-tabel, yaitu mengungkapkan pandangan pengusaha pada konflik yang dipersepsi dan dirasakan.

Hipotesis 2 yang diajukan, dibahas secara verifikatif digambarkan secara struktural melalui sebuah paradigma, yang secara diagramatik menggambarkan hubungan antar variabel. Dalam diagram tersebut perundangan (X1) mempengaruhi konflik yantg dirasakan (perceived conflict) dalam hubungan industrial (Y). Oleh karena itu hipotesis 2, dapat digambarkan dengan paradigma sebagai berikut :

Struktur Hubungan $\mathrm{X} 1$ dengan $\mathrm{Y}$

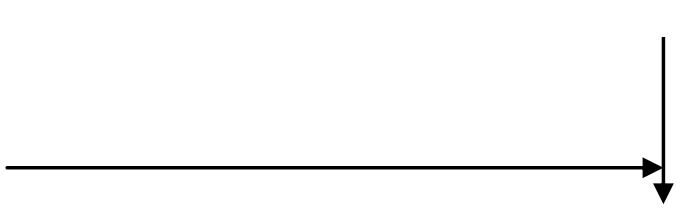


Koefisien korelasi (ryx1) dapat ditentukan dengan rumus :

$$
\mathrm{r}_{\mathrm{yxi}}=\frac{\mathrm{n} \sum_{\mathrm{h}=1}^{\mathrm{n}} \mathrm{X}_{\mathrm{ih}} \mathrm{Y}_{\mathrm{h}}-\left(\sum \mathrm{X}_{\mathrm{ih}}\right)\left(\sum \mathrm{Y}_{\mathrm{h}}\right)}{\sqrt{\left\{\mathrm{n} \sum_{\mathrm{h}=1}^{\mathrm{n}} \mathrm{X}_{\mathrm{ih}}{ }^{2}-\left(\sum \mathrm{X}_{\mathrm{ih}}\right)^{2}\right\}\left\{\mathrm{n} \sum_{\mathrm{h}=1}^{\mathrm{n}} \mathrm{Y}_{\mathrm{h}}{ }^{2}-\left(\sum_{\mathrm{h}=1}^{\mathrm{n}} \mathrm{Y}_{\mathrm{h}}{ }^{2}\right)\right\}}}
$$

$\mathrm{i}=1,2,3, \ldots, 5$ dan $\mathrm{k}=$ banyaknya variabel bebas

Pengaruh variabel lainnya dapat ditentukan melalui :

Px2E1 $=\sqrt{ } 1-r 2$ yxi $; i=1$

Hipotesis 3 yang diajukan, dibahas secara verifikatif digambarkan secara struktural melalui sebuah paradigma, yang secara diagramatik menggambarkan hubungan antar variabel. Dalam diagram tersebut nilai-nilai sosial (X2) mempengaruhi konflik dalam hubungan industrial $(\mathrm{Y})$. Oleh karena itu hipotesis 3, dapat digambarkan dengan paradigma sebagai berikut :

Struktur Hubungan X2 dengan $Y$

\section{E2}

Koefisien korelasi (ryx2) dapat ditentukan dengan rumus :

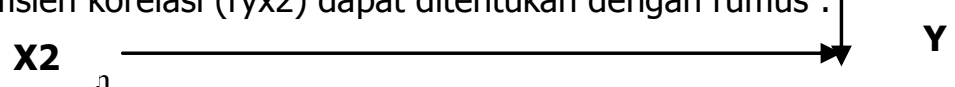

$$
\mathrm{r}_{\mathrm{yxi}}=\frac{\mathrm{n} \sum_{\mathrm{h}=1}^{\mathrm{n}} \mathrm{X}_{\mathrm{ih}} \mathrm{Y}_{\mathrm{h}}-\left(\sum \mathrm{X}_{\mathrm{ih}}\right)\left(\sum \mathrm{Y}_{\mathrm{h}}\right)}{\sqrt{\left\{\mathrm{n} \sum_{\mathrm{h}=1}^{\mathrm{n}} \mathrm{X}_{\mathrm{ih}}{ }^{2}-\left(\sum \mathrm{X}_{\mathrm{ih}}\right)^{2}\right\}\left\{\mathrm{n} \sum_{\mathrm{h}=1}^{\mathrm{n}} \mathrm{Y}_{\mathrm{h}}{ }^{2}-\left(\sum_{\mathrm{h}=1}^{\mathrm{n}} \mathrm{Y}_{\mathrm{h}}{ }^{2}\right)\right\}}}
$$

$\mathrm{i}=1,2,3, \ldots, 5$ dan $\mathrm{k}=$ banyaknya variabel bebas 
Pengaruh variabel lainnya dapat ditentukan melalui :

PyE2 $=\sqrt{ } 1-r 2 \times 2 x i ; i=1$

Hipotesis 4 yang diajukan, dibahas secara verifikatif digambarkan secara struktural melalui sebuah paradigma, yang secara diagramatik menggambarkan hubungan antar variabel. Dalam diagram tersebut hubungan kerja (X3) mempengaruhi konflik dalam hubungan industrial $(\mathrm{Y})$. Oleh karena itu hipotesis 4, dapat digambarkan dengan paradigma sebagai berikut :

Struktur Hubungan X3 dengan $Y$

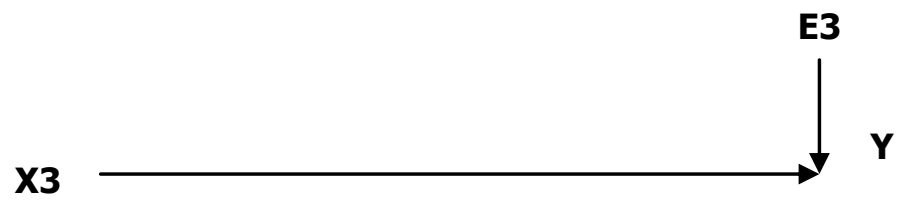

Koefisien korelasi (ryx3) dapat ditentukan dengan rumus :

$$
\mathrm{r}_{\mathrm{yxi}}=\frac{\mathrm{n} \sum_{\mathrm{h}=1}^{\mathrm{n}} \mathrm{X}_{\mathrm{ih}} \mathrm{Y}_{\mathrm{h}}-\left(\sum \mathrm{X}_{\mathrm{ih}}\right)\left(\sum \mathrm{Y}_{\mathrm{h}}\right)}{\sqrt{\left\{\mathrm{n} \sum_{\mathrm{h}=1}^{\mathrm{n}} \mathrm{X}_{\mathrm{ih}}{ }^{2}-\left(\sum \mathrm{X}_{\mathrm{ih}}\right)^{2}\right\}\left\{\mathrm{n} \sum_{\mathrm{h}=1}^{\mathrm{n}} \mathrm{Y}_{\mathrm{h}}{ }^{2}-\left(\sum_{\mathrm{h}=1}^{\mathrm{n}} \mathrm{Y}_{\mathrm{h}}{ }^{2}\right)\right\}}}
$$

$\mathrm{i}=1,2,3, \ldots, 5$ dan $\mathrm{k}=$ banyaknya variabel bebas

Pengaruh variabel lainnya dapat ditentukan melalui :

PyE3 $=\sqrt{ } 1-r 2 \times 3 \times i ; i=1$

Hipotesis 5 yang diajukan, dibahas secara verifikatif digambarkan secara struktural melalui sebuah paradigma, yang secara diagramatik menggambarkan hubungan antar variabel. Dalam diagram tersebut konflik dalam hubungan industrial (Y) mempengaruhi produktivitas kerja (Z). Oleh karena itu hipotesis 5, dapat digambarkan dengan paradigma sebagai berikut : 
Struktur Hubungan Y dengan Z

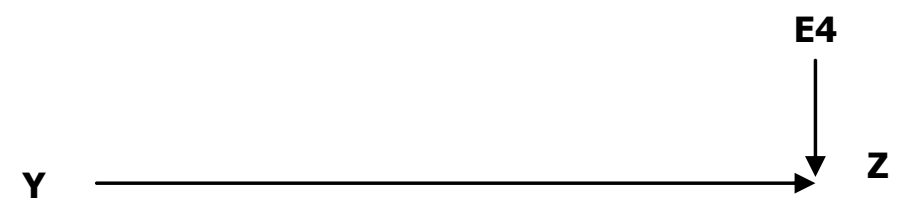

Koefisien korelasi (rzy) dapat ditentukan dengan rumus :

$$
\mathrm{r}_{\mathrm{yxi}}=\frac{\mathrm{n} \sum_{\mathrm{h}=1}^{\mathrm{n}} \mathrm{X}_{\mathrm{ih}} \mathrm{Y}_{\mathrm{h}}-\left(\sum \mathrm{X}_{\mathrm{ih}}\right)\left(\sum \mathrm{Y}_{\mathrm{h}}\right)}{\sqrt{\left\{\mathrm{n} \sum_{\mathrm{h}=1}^{\mathrm{n}} \mathrm{X}_{\mathrm{ih}}{ }^{2}-\left(\sum \mathrm{X}_{\mathrm{ih}}\right)^{2}\right\}\left\{\mathrm{n} \sum_{\mathrm{h}=1}^{\mathrm{n}} \mathrm{Y}_{\mathrm{h}}{ }^{2}-\left(\sum_{\mathrm{h}=1}^{\mathrm{n}} \mathrm{Y}_{\mathrm{h}}{ }^{2}\right)\right\}}}
$$

$\mathrm{i}=1,2,3, \ldots, 5$ dan $\mathrm{k}=$ banyaknya variabel bebas

Pengaruh variabel lainnya dapat ditentukan melalui :

PyE4 $=\sqrt{ } 1-r 2 z y ; i=1$

\section{HASIL DAN PEMBAHASAN}

Berdasarkan hasil analisis, sumber-sumber penyebab timbulnya konflik yang dipersepsi oleh pengusaha adalah dapat dirangkum sebagai berikut :

1. Konflik yang terjadi akibat adanya ambiugitas peranan.

2. Konflik yang timbul akibat persaingan untuk mencapai sumberdaya yang langka.

3. Konflik yang terjadi akibat interdependensi tugas.

4. Konflik yang timbul akibat konflik sebelumnya yang belum teratasi secara menyeluruh.

5. Konflik yang terjadi akibat perbedaan persepsi individu.

6. Konflik yang terjadi sebagai akibat perbedaan kepribadian, nilai-nilai dan tujuan.

Tabel di bawah memperlihatkan skor rata-rata mengenai persepsi pengusaha pada faktor-faktor penyebab timbulnya konflik secara keseluruhan, sehingga dapat diketahui sejauhmana gejala-gejala konflik yang timbul di lingkungan perusahaan 
dapat dipersepsi oleh para pengusaha sebagai penyebab konflik dalam hubungan industrial.

Tabel 1. Persepsi pengusaha pada faktor-faktor penyebab timbulnya konflik

\begin{tabular}{lc}
\hline Penyebab Konflik yang Dipersepsi Pengusaha & $\begin{array}{c}\text { Rata-rata } \\
\text { Skor }\end{array}$ \\
\hline Ambiguitas Peranan & 174.5 \\
Persaingan Untuk Mencapai Sumber Daya yang Langka & 149 \\
Interdependensi tugas & 175.5 \\
Konflik Sebelumnya yang Belum Teratasi & 177.5 \\
Perbedaan Persepsi Individu & 211.5 \\
Perbedaan Kepribadian, Nilai-nilai, dan Tujuan & 209.5 \\
\hline Rata-rata Total & 182.92
\end{tabular}

Keterangan : Skor digunakan untuk melihat objektifitas nilai persepsi pengusaha

Berdasarkan Tabel 2, terlihat bahwa secara keseluruhan rata-rata skor konflik yang dipersepsi pengusaha $(182,92)$ lebih kecil dari pada konflik yang dirasakan pengusaha $(214,9)$. Hal ini menunjukkan bahwa pengusaha kurang memperhatikan gejala konflik secara keseluruhan yang akhirnya terjadi manifestasi konflik dalam bentuk demonstrasi, pemogokan kerja, dan protes-protes keras dari para pekerja yang tentunya akan merugikan kedua belah pihak, karena disinyalir pengusaha sudah terbiasa menekan konflik pada jaman orde baru dengan menggunakan kekuatan pengusaha dan pemerintah yang selalu mendukung mereka, serta mereka umumnya berhasil, tetapi setelah adanya perubahan politik (orde reformasi) kebebasan untuk berpendapat menjadi sangat leluasa, sehingga konflik yang betahun-tahun laten menjadi tereskalasi dan akhirnya konflik terbuka (manifes konflik) (Susetiawan, 2000:79).

Dari hasil penelitian di lapangan ternyata para Pengusaha Perusahaan Garmen di Wilayah Bandung dan sekitarnya masih berpandangan tradisional terhadap konflik dan gejala-gejala konflik yang sangat diperhatikan oleh mereka adalah perbedaanperbedaan dalam nilai-nilai, kebutuhan, kepribadian, persepsi, dan tujuan, walaupun pada kenyataannya perbedaan-perbedaan tersebut relatif jarang menimbulkan konflik.

Perundang-undangan cukup mempengaruhi konflik dalam hubungan industrial, karena perundang-undangan merupakan aturan pemerintah yang harus ditaati oleh pengusaha dan pekerja, sehingga apabila perundang-undangan yang dibuat mendukung/ menguntungkan pada salah satu pihak terutama menguntungkan pihak 
Konflik Dalam Hubungan Industrial Ditinjau Dari Aspek Sosiologi Industri: Suatu Survey Pada Industri Garmen di Kabupaten Bandung (Nandan Limakrisna)

pengusaha, maka akan timbul gejolak protes/ demo yang akhirnya akan menimbulkan konflik yang terbuka, jika pengusaha atau pemerintah tidak responsif untuk mengantisifasi gejala-gejala konflik yang timbul.

Tabel 2. Gejala-gejala konflik yang timbul di lingkungan perusahaan

\begin{tabular}{lccc}
$\begin{array}{l}\text { Gejala-gejala Penyebab } \\
\text { Timbulnya Konflik }\end{array}$ & $\begin{array}{c}\text { Konflik yang } \\
\text { Dipersepsi } \\
\text { (Manajer } \\
\text { Perseption to } \\
\text { Conflict) } \\
\text { MP }\end{array}$ & $\begin{array}{c}\text { Konflik yang } \\
\text { Dirasakan } \\
\text { (Perceived } \\
\text { Conflict) } \\
\text { P }\end{array}$ & $\begin{array}{c}\text { Manifestasi } \\
\text { Konflik } \\
\text { (Conflict Gap) } \\
\text { MP - P }\end{array}$ \\
\hline $\begin{array}{l}\text { Ambiguitas Peranan } \\
\begin{array}{l}\text { Persaingan Untuk Mencapai } \\
\text { Sumber Daya yang Langka }\end{array}\end{array}$ & 174.5 & 241 & $(66.5)$ \\
$\begin{array}{l}\text { Interdependensi tugas } \\
\text { Konflik Sebelumnya yang Belum } \\
\text { Teratasi }\end{array}$ & 179 & 245 & $(96)$ \\
$\begin{array}{l}\text { Perbedaan Persepsi Individu } \\
\begin{array}{l}\text { Perbedaan Kepribadian, Nilai- } \\
\text { nilai, dan Tujuan }\end{array}\end{array}$ & 211.5 & 219 & $(43.5)$ \\
\hline Rata-rata Total & 209.5 & 216.5 & $(39)$ \\
\hline
\end{tabular}

Akan tetapi perbedaan nilai-nilai sosial pekerja dengan pengusaha tidak begitu mempengaruhi konflik dalam hubungan industrial, karena walaupun nilai-nilai sosial antara pengusaha dan pekerja berbeda, akan tetapi pengusaha masih dapat menyesuaikan nilai-nilai sosial yang dianut oleh mereka dengan nilai-nilai sosial yang dianut oleh para pekerja, misalnya memberikan tunjangan hari raya/ mendukung perkembangan kebudayaan setempat, menggunakan nilai-nilai budaya yang dianut oleh pekerja dan masyarakat setempat, ketersediaan tempat beribadah, sarana kesehatan dan keselamatan kerja.

Ketidakharmonisan hubungan kerja antara pengusaha dengan pekerja cukup mempengaruhi konflik dalam hubungan industrial, hal itu ditandai dengan seringnya konflik antar mereka dan juga dengan pemerintah yang masih perlu penyelesaian secara positif dan efektif, karena hubungan kerja antara atasan dan bawahan dalam mencapai tujuan bersama mutlak harus terjalin kerjasama yang harmonis, artinya membentuk suatu sistem kerja yang baik dan team work yang kompak untuk mencapai tujuan perusahaan secara efektif dan efesien. Kurang baiknya kerjasama 
antara atasan dan bawahan, disebabkan tidak tertransformasikan visi/ misi dan tujuan perusahaan pada semua fihak yang terkait di perusahaan termasuk para pekerja, sehingga arah yang dituju oleh para pengusaha dengan para pekerja menjadi berbeda, yang akhirnya timbul gejala-gejala konflik dan tidak menutup kemungkinan jika pengusaha tidak responsif dalam mengantisifasi situasi tersebut, maka akan terjadi konflik yang terbuka.

Konflik dalam hubungan industrial sangat mempengaruhi produktivitas kerja. Hal tersebut dapat dilihat dari aspek-aspek dalam hubungan industrial, yaitu: pandangan pengusaha yang tradisional mengenai konflik, adanya perundang-undangan yang tidak aspiratif, dan hubungan kerja antara pengusaha dengan pekerja yang kurang harmonis. Aspek-aspek tersebut yang dapat menimbulkan konflik yang sekaligus berdampak pada penurunan produktivitas kerja.

\section{SIMPULAN}

Dari hasil penelitian di lapangan ternyata para Pengusaha Perusahaan Garmen di Wilayah Bandung dan sekitarnya masih berpandangan tradisional terhadap konflik dan gejala-gejala konflik yang sangat diperhatikan oleh mereka adalah perbedaanperbedaan dalam nilai-nilai, kebutuhan, kepribadian, persepsi, dan tujuan, walaupun pada kenyataannya perbedaan-perbedaan tersebut relatif jarang menimbulkan konflik.

Perundang-undangan cukup mempengaruhi konflik dalam hubungan industrial, karena perundang-undangan merupakan aturan pemerintah yang harus ditaati oleh pengusaha dan pekerja, sehingga apabila perundang-undangan yang dibuat mendukung/ menguntungkan pada salah satu pihak terutama menguntungkan pihak pengusaha, maka akan timbul gejolak protes/ demo yang akhirnya akan menimbulkan konflik yang terbuka, jika pengusaha atau pemerintah tidak responsif untuk mengantisifasi gejala-gejala konflik yang timbul.

Akan tetapi perbedaan nilai-nilai sosial pekerja dengan pengusaha tidak begitu mempengaruhi konflik dalam hubungan industrial, karena walaupun nilai-nilai sosial antara pengusaha dan pekerja berbeda, akan tetapi pengusaha masih dapat menyesuaikan nilai-nilai sosial yang dianut oleh mereka dengan nilai-nilai sosial yang dianut oleh para pekerja, misalnya memberikan tunjangan hari raya/ mendukung perkembangan kebudayaan setempat, menggunakan nilai-nilai budaya yang dianut oleh pekerja dan masyarakat setempat, ketersediaan tempat beribadah, sarana kesehatan dan keselamatan kerja.

Ketidak harmonisan hubungan kerja antara pengusaha dengan pekerja cukup mempengaruhi konflik dalam hubungan industrial, hal itu ditandai dengan seringnya konflik antar mereka dan juga dengan pemerintah yang masih perlu penyelesaian secara positif dan efektif, karena hubungan kerja antara atasan dan bawahan dalam mencapai tujuan bersama mutlak harus terjalin kerjasama yang harmonis, artinya 
Konflik Dalam Hubungan Industrial Ditinjau Dari Aspek Sosiologi Industri: Suatu Survey Pada Industri Garmen di Kabupaten Bandung (Nandan Limakrisna)

membentuk suatu sistem kerja yang baik dan team work yang kompak untuk mencapai tujuan perusahaan secara efektif dan efesien. Kurang baiknya kerjasama antara atasan dan bawahan, disebabkan tidak tertransformasikan visi/ misi dan tujuan perusahaan pada semua fihak yang terkait di perusahaan termasuk para pekerja, sehingga arah yang dituju oleh para pengusaha dengan para pekerja menjadi berbeda, yang akhirnya timbul gejala-gejala konflik dan tidak menutup kemungkinan jika pengusaha tidak responsif dalam mengantisifasi situasi tersebut, maka akan terjadi konflik yang terbuka.

Konflik dalam hubungan industrial sangat mempengaruhi produktivitas kerja. Hal tersebut dapat dilihat dari aspek-aspek dalam hubungan industrial, yaitu: pandangan pengusaha yang tradisional mengenai konflik, adanya perundang-undangan yang tidak aspiratif, dan hubungan kerja antara pengusaha dengan pekerja yang kurang harmonis. Aspek-aspek tersebut yang dapat menimbulkan konflik yang sekaligus berdampak pada penurunan produktivitas kerja.

Para pengusaha Garmen di Wilayah Bandung dan sekitarnya, harus berusaha untuk merubah sudut pandang mereka yang semula tradisional menjadi interaksionis / maju / modern mengenai konflik. Harus lebih berani mengintrodusir model konflik yang bersifat dinamis-kreatif, karena tuntutan perubahan lingkungan saat ini sangat cepat dan dalam rangka menghadapi globalisasi, sehingga harus mengoptimalkan potensi sumber daya manusia yang dimiliki dengan berbagai perbedaan-perbedaannya untuk meningkatkan daya saing perusahaan dimasa yang akan datang.

Pemerintah sebagai pemberi kebijakan dengan dikendalikan oleh para wakil rakyat senantiasa bekerja sama antar mereka sebagai lembaga tinggi negara untuk membuat perundang-undangan yang aspiratif, khususnya bagi pekerja dan pengusaha serta umumnya bagi masyarakat secara keseluruhan dalam rangka mencapai tujuan pembangunan nasional, yaitu untuk menciptakan masyarakat yang adil dan makmur. Karena itu rakyat dalam hal ini pengusaha dan pekerja memerlukan dukungan yang sama untuk meningkatkan kesejahteraan mereka, dengan demikian secara bertahap tetapi pasti kemakmuran seluruh bangsa Indonesia akan tercapai.

Pengusaha mesti memanfaatkan nilai-nilai sosial positif yang mencerminkan kebutuhan dan dianut oleh pekerja untuk kesejahteraan bersama.

Hubungan kerja yang harmonis antara pekerja dan pengusaha dalam hubungan industrial perlu dipelihara dan ditingkatkan, dalam arti saling mengisi, bekerja sama untuk kemajuan bersama (bukan asal manut). Produktivitas kerja pekerja yang positif dan efektif akan terpenuhi, jika pengusaha memenuhi kebutuhan dan keinginan mereka secara proforsional, demikian juga sebaliknya, sehingga hak dan kewajiban kedua belah pihak dapat terpenuhi dan terjalin rasa saling menghargai, menghormati, dan menyayangi. Dalam penelitian ini fokus pembahasan pada gelaja-gejala konflik. Untuk peneliti yang lebih lanjut, agar diteliti mengenai pengelolaan konflik yang baik 
sesuai dengan situasi dan kondisi saat ini, sebelum terjadi, sedang terjadi, dan setelah terjadi konflik yang belum dibahas pada penelitian ini, serta bagaimana untuk mengubah pandangan pengusaha dari tradisional kepada modern mengenai konflik.

\section{DAFTAR PUSTAKA}

Al-Rasyid, Harun. 1998. Diktat Analisis Jalur. Bandung : Universitas Padjadjaran

Arikunto, Suharsimi, 1996. Manajemen Penelitian. PT. Pustaka Binaman Presindo, Yogyakarta.

Bernardin, H.J and Russel, JEA. 1993. Human Resources Management, New York: Mc. Graw Hill, Inc.

Cascio, WF. 1998. Managing Human Resources, New York: Mc.Graw Hill, Inc.

David J. Cherrington. 1989., Job Satisfaction, New York, Mc Grawe Hill.Inc.

Dessler, Garry. 1997. Managing Human Resources, New York.: Mc.Graw Hill, Inc.

Franch. Wendell L. 1998. Human Resources Management, New York: Houghton Miffin Company.

Flippo, Edwin B. 1996. Manajemen Personalia, diterjemahkan oleh Moh. Mas'ud. Jakarta, Erlangga.

Haque and Falk. 2000. Measuring Job Productivity. Journal of Human Resource Managemen, Emerald, London.

Heijrachman, R. \& Husnan, Suad. 1997. Manajemen Personalia. Yogyakarta. BPFE.

Wursanto, I. G. 1989. Manajemen Kepegawaian, Yogyakarta, Kanisius.

Milkovich, G.T. and Boudreau, J.W. 1997. Human Resources Management, Boston. Irwin, Inc.

Nasution, Mulya. 1994. Manajemen Personalia, Jakarta, Jambatan. 
Konflik Dalam Hubungan Industrial Ditinjau Dari Aspek Sosiologi Industri: Suatu Survey Pada Industri Garmen di Kabupaten Bandung (Nandan Limakrisna)

Putti, J.M. \& Toh T.S. 1988. Cases In Human Resources Management, Federal Publications. Pte.Ltd.

Putti, J.M. 1988. A. Manager's Primer On Performance Appraisals: Concepts and Technique. Federal Publications. Pte.Ltd.

Tan. C.H. \& Torrington, Deren. 1998. Human Resources Management For South East Asia and Hongkong, Singapore: Prentice Hall.

Stoner, James A.F. 1995. Management. New Jersey: Prentice Hall International Edition. 